\title{
BMJ Open Quality A Message For You: a novel communication tool developed in response to the COVID-19 pandemic
}

\author{
Natalia Cotton, ${ }^{1}$ Oliver Mitchell, ${ }^{1,2}$ Olivia Buckeldee, ${ }^{1}$ Rory Morrice (iD,${ }^{3}$ \\ Victoria Lyon, ${ }^{1}$ Brent Bartholomew ${ }^{1}$
}

To cite: Cotton N, Mitchell 0, Buckeldee 0, et al. A Message For You: a novel communication tool developed in response to the COVID-19 pandemic. BMJ Open Quality 2021;10:e001160. doi:10.1136/ bmjoq-2020-001160

Received 15 August 2020 Accepted 6 June 2021
Check for updates

(c) Author(s) (or their employer(s)) 2021. Re-use permitted under CC BY-NC. No commercial re-use. See rights and permissions. Published by BMJ.

${ }^{1}$ Undergraduate Education, Chelsea and Westminster Hospital NHS Foundation Trust, London, UK

${ }^{2}$ Undergraduate Medicine, Imperial College London Faculty of Medicine - South Kensington Campus, London, UK

${ }^{3}$ Undergraduate Education, West Middlesex University Hospital, Isleworth, UK

Correspondence to Dr Oliver Mitchell; oliver.mitchell1@nhs.net

\section{BACKGROUND}

During the COVID-19 pandemic, hospitals across the UK had to restrict inpatient visitors in order to help prevent the spread of the virus. ${ }^{1}$ On 24 March 2020, Chelsea and Westminster National Health Service (NHS) Trust stopped allowing visitors to its wards apart from in exceptional circumstances. For patients and families alike, this cut-off a vital source of communication and comfort during a time of already heightened anxiety. Restriction of visitors may contribute to feelings of loneliness and isolation, ${ }^{2}$ which in turn have been shown to predict increased morbidity and mortality. ${ }^{3}$ These issues of in-hospital isolation, secondary to reduced social contact with loved ones as a result of the COVID-19 pandemic, represent our problem statement, which we attempted to address with the project outlined below.

Here, we describe the implementation of a novel message delivery service with a view to improving communication between inpatients and their loved ones. This service, called 'A Message for You', was launched across two hospital sites using the help of medical students volunteering at the trust while clinical placements were suspended.

For this paper, we have focused on two project aims:

1. To successfully deliver $90 \%$ of the messages we received.

2. To deliver cards to $5 \%$ of the inpatient population.

Due to the unprecedented nature of the pandemic, no national guidance was available to guide our project aims. We set target one at $90 \%$ as we were only able to deliver the cards on weekdays, and therefore, predicted that some cards would not be delivered due to patient discharges over the weekend. Based on the total number of in-patient beds in the hospital, and the total number of new admissions per day, we felt that delivering cards to $5 \%$ of the inpatient population (approximately 55 cards/week) would be near to the maximum number of cards we would be able to deliver, given the number of medical students volunteering with us at the time.

\section{METHODS}

A number of potential interventions were considered to increase social contact between patients and their loved ones. The various considerations and interventions are outlined in figure 1.

Following conversations with infection control and estates, it was decided that there was insufficient space on the wards to allow visitors to be present and for social distancing to occur. The hospital had started to buy iPads for inpatients to use, however, the palliative care team highlighted that there were a subset of patients who were unable to use this technology due to their clinical state. There was also an insufficient supply of iPads to match patient demand at this point, and so the service was limited to patients nearing the end of their life. In addition, numerous patients were struggling to contact their relatives using their mobile phones as reception on the wards was poor. We, therefore, decided to establish a ward-based card delivery service.

We created an online portal on the trust website where family and friends of inpatients across both sites within the Chelsea and Westminster NHS Trust could submit a written message and a photo. These were then printed onto a card template and delivered daily to the patient bedside by the medical student volunteers from Monday to Friday. In order to maintain patient confidentiality, a dedicated, secure NHS email was used to process the submitted messages and only staff that had received information governance training were able to access patient identifying information. 


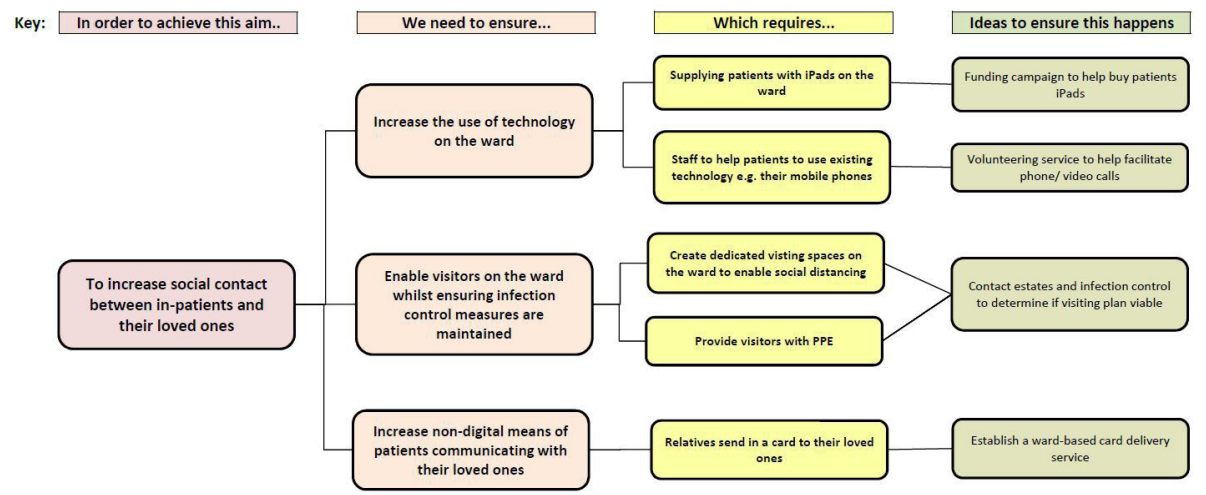

Figure 1 Driver diagram outlining different possible interventions to increase social contact between patients and their loved ones. (PPE - Personal Protective Equipment).

To increase uptake of the service, we implemented three three cumulative cycles of advertising.

- Cycle 1 (week 1): the project was advertised via posts on trust social media.

- Cycle 2 (weeks 2, 3 and 4): the project was advertised on the front page of the trust website.

- Cycle 3 (weeks 5, 6 and 7): the project was advertised to medical and nursing staff face to face and via email. Furthermore, leaflets were distributed in Accident and Emergency (A\&E) so staff could directly advertise the service to friends and families during their dayto-day communications.

At the end of the study period, a brief survey was emailed to individuals who had submitted a card via the online portal. The email stated that participation in the survey was entirely optional and they were under no obligation to take part.

\section{RESULTS}

In total, we received 184 cards addressed to 75 patients. Nighty-eight per cent of cards were delivered successfully. Of the four cards that we were unable to deliver, three cards were addressed to patients that were discharged by the time of delivery. The final, non-delivered card was submitted to a patient who had unfortunately passed away by the time of delivery.

Figure 2 illustrates the weekly total number of recipients and cards delivered during each of the three cycles. The number of weekly recipients rose from 8 in week 1 to a peak of 15 in week 4, coinciding with the implementation of cycle 2. During the same period, the number of cards delivered rose from 9 to 45 . On average, each patient received 3.5 cards from two separate senders. The percentage of the inpatient population that received cards varied from $2 \%$ (week 1) and $4 \%$ (week 4).

Table 1 demonstrates the results of our user feedback survey $(n=20)$. Seventy per cent became aware of the service via the Trust website. Most users found the service to be an easy way of maintaining communication with their loved ones.

\section{DISCUSSION}

We successfully met our card delivery target (aim 1), however, we delivered cards to less than $5 \%$ of the

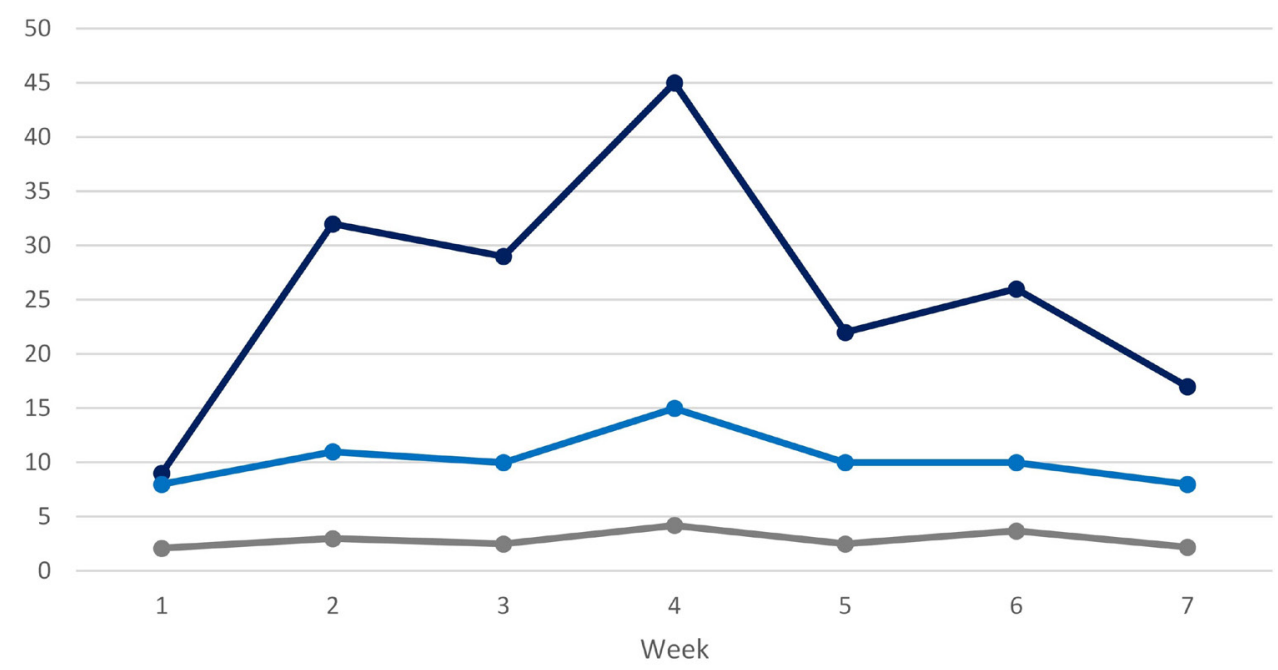

- Total cards delivered $\longrightarrow$ Number of different recipients $\longrightarrow$ Percentage of inpatient population

Figure 2 The total number of recipients and cards delivered over the 7-week study period. 
Table 1 Summary of the user survey feedback

\begin{tabular}{|c|c|c|}
\hline Question & Option & No $(\%)$ \\
\hline \multirow{4}{*}{$\begin{array}{l}\text { How did become } \\
\text { aware of our 'A } \\
\text { Message For You' } \\
\text { service? }\end{array}$} & Trust website & $14(70)$ \\
\hline & Social media & $1(5)$ \\
\hline & Word of mouth & $4(25)$ \\
\hline & Doctor/nurse & $1(5)$ \\
\hline \multirow{5}{*}{$\begin{array}{l}\text { Have you also been } \\
\text { in contact with your } \\
\text { loved one using other } \\
\text { means? }\end{array}$} & Yes-Phone call & $1(5)$ \\
\hline & Yes-Video call & $1(5)$ \\
\hline & Yes-Text message & $3(15)$ \\
\hline & Yes-Other & $2(10)$ \\
\hline & No & $13(65)$ \\
\hline
\end{tabular}

\begin{tabular}{|c|c|c|}
\hline \multirow{5}{*}{$\begin{array}{l}\text { On scale of } 1-5 \text {, how } \\
\text { much do you agree } \\
\text { with the following } \\
\text { statement: I found the } \\
\text { 'A Message For You' } \\
\text { online portal easy to } \\
\text { use. }\end{array}$} & 1 (strongly disagree) & 0 \\
\hline & 2 (disagree) & 0 \\
\hline & $\begin{array}{l}3 \text { (neither agree nor } \\
\text { disagree) }\end{array}$ & $1(5)$ \\
\hline & 4 (agree) & $6(30)$ \\
\hline & 5 (strongly agree) & $13(65)$ \\
\hline
\end{tabular}

On scale of $1-5$, how 1 (strongly disagree)

much do you agree

with the following

statement: The 'A

Message For You'

helped me stay in

contact with my loved

ones in hospital

$\begin{array}{lll}\text { On scale of } 1-5, \text { how } & 1 \text { (strongly disagree) } & 0 \\ \text { much do you agree } & 2 \text { (disagree) } & 2(10) \\ \text { with the following } & 3 \text { (neither agree nor } & 3(15) \\ \text { statement: The 'A } & \text { disagree) } & \\ \begin{array}{l}\text { Message For You' let } \\ \text { my loved one know }\end{array} & 4 \text { (agree) } & 6(30) \\ \begin{array}{l}\text { I was thinking about } \\ \text { them. }\end{array} & 5 \text { (strongly agree) } & 9(45)\end{array}$

Free-text comments 'It was absolutely brilliant'

'It felt personal, easy to use and having something tangible that is, a card added something that you cannot get over the phone/text etc'

'I liked that we could upload photos too, I really appreciated the messages were read to ${ }^{* \star \star \star}$ and the pictures were pinned up for her to see'

'Thank you so very much to all involved in this and for your outstanding care' 'The fact I felt like my friend could hear my messages in ICU'

'It's a great emotional boost for a patient!'

'Helped **** feel less isolated because people were unable to visit him for a few weeks. Thank you very much for this excellent service.'

inpatient population (aim 2). Interestingly, many people received multiple cards during their inpatient stay. This implies that it is difficult to make people aware of the service, but once they start using the service, they are keen to continue sending messages. This is echoed in the results of our feedback survey which demonstrated high levels of user satisfaction. Most users became aware of the service via the trust website which should be considered if the service is replicated in other trusts.

One limitation of our study is that we were unable to formally survey patients for their perception of the service as many patients were very unwell. However, we know that treating patients holistically, meeting their personal and clinical needs, results in better outcomes. ${ }^{45}$

Between July and November 2020, visiting restrictions in the hospital were eased. However, the use of the service remained at similar levels to that during the height of the pandemic. This suggests that this service may also be useful for people unable to travel to visit their lovedones in hospital for reasons unrelated to the current pandemic, such as geographical or health reasons. For example, during the study period, cards were submitted from as far as Japan, Germany and Turkey.

In addition to this service, the hospital ran other projects designed to enhance communication between patients and loved ones, for example by facilitating videocalls between family members. However, these projects were both time and resource intensive and were unsuitable for patients who were acutely unwell. As such, the 'A Message For You' service represented a resource-effective way of facilitating communication in addition to other services rather than instead of them. Indeed, for many people, we surveyed this service represented their only form of communication with their loved one.

During this transition, concerns were raised about the ability of volunteers to take over the service due to the time commitment involved. We estimate that it takes approximately 10-15 min to print and deliver each card to a patient. We delivered between 8 and 40 cards each week, amounting to approximately 1-2 hours of work each day. Posters and leaflets advertising the service were provided by volunteers. We estimate that printing and delivering these took approximately $30 \mathrm{~min}$ per week. However, we managed to mitigate some of this time commitment by combining delivery of cards with other activities that volunteers undertake each day on the wards. In addition, the hospital communications team took over the promotion of the project on social media and on the hospital website.

As of December 2020, the service continues to operate successfully under the guidance of the hospital volunteering service, indicating that this is a sustainable model going forward. In the future, we hope to gather information from healthcare professionals regarding their experience of the service in order to explore potential barriers to wider uptake and implementation in order to continue to improve the service.

Contributors NC and OM were the principal investigators. NC and OM were responsible for the study design, data collection, data analysis and drafting of the manuscript. $\mathrm{OB}$ and $\mathrm{RM}$ were involved in the study design, data collection and drafting of the manuscript. VL and BB were involved in the study design and drafting of the manuscript. All participants gave permission for submission of this manuscript and agreed to be responsible for any published work. 
Funding The authors have not declared a specific grant for this research from any funding agency in the public, commercial or not-for-profit sectors.

Competing interests None declared.

Patient and public involvement Patients and/or the public were not involved in the design, or conduct, or reporting, or dissemination plans of this research.

Patient consent for publication Not required.

Ethics approval Ethical approval was not sought as our project was carried out for quality improvement purposes. The project was registered as a quality improvement project with the trust on 3 July 2020.

Provenance and peer review Not commissioned; externally peer reviewed.

Open access This is an open access article distributed in accordance with the Creative Commons Attribution Non Commercial (CC BY-NC 4.0) license, which permits others to distribute, remix, adapt, build upon this work non-commercially, and license their derivative works on different terms, provided the original work is properly cited, appropriate credit is given, any changes made indicated, and the use is non-commercial. See: http://creativecommons.org/licenses/by-nc/4.0/.
ORCID iD

Rory Morrice http://orcid.org/0000-0002-7383-057X

\section{REFERENCES}

1 NHS. Visiting someone in hospital. Available: https://www.nhs.uk/ using-the-nhs/nhs-services/hospitals/visiting-someone-in-hospital/ [Accessed 8 Jul 2020].

2 Barratt RL, Shaban R, Moyle W. Patient experience of source isolation: lessons for clinical practice. Contemp Nurse 2011;39:180-93.

3 Hawkley LC, Cacioppo JT. Loneliness matters: a theoretical and empirical review of consequences and mechanisms. Ann Behav Med 2010;40:218-27.

4 Jasemi M, Valizadeh L, Zamanzadeh V, et al. A concept analysis of holistic care by hybrid model. Indian J Palliat Care 2017;23:71-80.

5 Akinyanju OO, Otaigbe Al, Ibidapo MOO. Outcome of holistic care in Nigerian patients with sickle cell anaemia. Clin Lab Haematol 2005;27:195-9. 